\title{
In Vitro Inhibition Against Angiotensin Converting Enzyme by Sonchus arvensis Water Extract and Fractions as Antihypertension
}

\author{
Trivadila, Lufthiah Hasnah Iramani, Novriyandi Hanif, Sekar Ilma Tiarani, Min Rahminiwati, Dyah Iswantini* \\ Department of Chemistry, Faculty of Mathematics and Natural Sciences \\ Tropical Biopharmaca Research Center \\ IPB University \\ Bogor, Indonesia \\ *dyahis@apps.ipb.ac.id
}

\begin{abstract}
Hypertension is a condition in which a person has an elevating in blood pressure above normal, resulting in an increasing in morbidity and mortality. One mechanism of treating hypertension is by inhibiting the formation of angiotensin converting enzyme (ACE). Sonchus arvensis, known as tempuyung, widely used in treating various diseases, such as diuretic, anti-inflammatory, and antihypertensive The purpose of this study was to test the in vitro inhibition of single extracts, namely polar layer $\mathrm{BuOH}$, semipolar layer $\mathrm{CH}_{2} \mathrm{Cl}_{2}$, and nonpolar layer $n$-hexane of the tempuyung leaves toward ACE activity and compare their activity with a synthetic drugs (captopril). The sample were percolated in water, partitioned, and gave three layers. The polar $\mathrm{BuOH}$ layer exhibited the highest inhibition percentage of $45 \%$, followed by $\mathrm{CH}_{2} \mathrm{Cl}_{2}$ layer with $42 \%$, and $n$ hexane layer by $39 \%$, while the captopril showed inhibition of $48 \%$. The BuOH layer is potential to be developed for antihypertensive drug through the ACE inhibition mechanism, as indicated by the close to captopril inhibitory capacity in vitro.
\end{abstract}

Keywords-angiotensin converting enzyme, antihypertension, inhibitor, Sonchus arvensis, tempuyung

\section{INTRODUCTION}

Hypertension is a condition in which a person has increased blood pressure above normal, and increased morbidity and mortality [1]. High blood pressure indicated by systolic above $140 \mathrm{mmHg}$ and diastolic above $90 \mathrm{mmHg}$. Ninety percent of the causes of hypertension don't have specific symptoms which can be fatal. This disease can also result in complications with damage to the brain, eyes, heart, and kidneys [2]. The World Health Organization (WHO) states that hypertension is the number one cause of death in the world. Data Joint National Committee on Prevention, Detection, Evaluation, and Treatment on High Blood Pressure VII reports that nearly one billion people in the world have hypertension [3]. The results of Basic Health Research (Riskesdas) showed the prevalence of hypertension in people over 18 years of age in Indonesia was $25.8 \%$ in 2013 and increased significantly to $34.1 \%$ in 2018 [4].

The pathophysiological mechanism of hypertension is regulated by the renin angiotensin system (RAS). RAS is known as a circulatory or hormonal system that regulates blood pressure and homeostasys electrolyte and body fluids. RAS consists of three components, namely renin, angiotensinogen and angiotensin converting enzyme (ACE) [5]. Through the enzymatic chain reaction of the RAS, ACE converts angiotensin I to angiotensin II scheme (1).

ACE is a glycoprotein peptidylipeptide hydrolase which belongs to the class of hydrolase and requires zinc and chloride compounds to get its active blank. In addition to its main function in catalyzing the blankation of angiotensin II, ACE is a multifunctional enzyme that can also catalyze the degradation of bradykinin (a vasodilator that can dilate blood vessels) and enkephalin (a hormone that relaxes the mind). Therefore, inhibition of ACE activity can reduce the role of angiotensin II and can increase rates of bradykinin and enkephalin, so that it will decrease blood pressure [6]. A commercial product of an antihypertensive drug with an ACE inhibiting mechanism is captopril. Captopril has a high affinity toward ACE and competes with substrates to prevent the blankation of angiotensin II [7]. The use of captopril as an antihypertensive drug is a long-term treatment or even a lifetime treatment so that it can cause dangerous side effects. The side effects of using captopril that have been identified include hypotension, kidney failure, angioneurotic edema, and dry cough [8]. 


\section{Angiotensin I \\ ACE \\ Angiotensin II \\ Asp-Arg-Val-Try-Ile-His-Pro-Phe-His-Leu \\ Asp-Arg-Val-Try-Ile-His-Pro-Phe + His-Leu}

Scheme 1 Formation reaction of angiotensin II by ACE

The side effects of using synthetic drugs have prompted public attention to use herbal medicines derived from medicinal plants. Medicinal plants are plants that are cultivated as a cure for disease or as an intake to support public health [9]. One of the medicinal plants known to have an antihypertensive efficacy is the Sonchus arvensis (tempuyung). Tempuyung is a family of Asteraceae, a member of the second largest family in the kingdom plantae system [10]. This plant comes from Eurasia and grows wild in the open at an altitude of 50-1650 mesh [11]. In addition to its antihypertensive efficacy, tempuyung is also known to treat fever, inflammation, kidney stone destroyer, gout, and has antibacterial activity. Because of the many benefits found, this plant has attracted the attention of many researchers. Sulaksana et al [12] reported that tempuyung leaves contains mineral salts such as potassium, magnesium, and sodium, and contain anthraquinone compounds [9], triterpenoids [13], and phenolic acid [14]. Previous phytochemical test on tempuyung leaves extract and found that the tempuyung leaves extract positively contained flavonoids, saponins, tannins, quinones, polyphenols, monoterpenes and sesquiterpene compounds. Tempuyung leaves extract also contain alkaloids, glycosides. Tempuyung research is determined by the National Agency of Drug and Food Control as one of the thirteen superior species of native Indonesian medicine [15].

Budiman [16] has researched the ACE inhibition of a mixture of tempuyung and gotu kola extracts (Centella asiatica) with the combined extract of tempuyung gotu kola produced lower inhibition power than a single extract of gotu kola. The composition of gotu kola and tempuyung (1: 2) produced inhibition percentage of $44.88 \%$. The single extracts of gotu kola and tempuyung produced $53.86 \%$ and $30.50 \%$ of inhibition percentage. Yulinda [17] has researched the inhibition of cat whiskers extract (Orthosiphon stamineus), sambiloto (Andropaghis paniculata), gotu kola, and tempuyung toward ACE. The combination of them has an inhibition percentage of $59.27 \%$ to inhibit ACE. Amalia [18] has researched the ACE inhibition of a combination of tempuyung and gotu kola extracts in male white rats (Sprague Dawley) and its mechanism of action in vitro, this study gave result positively for a $20 \%$ reduction in blood pressure. Based on several previous studies, the inhibition of tempuyung leaves extract based on differences in polarity, compounds that act as inhibitors, and the mechanism of ACE inhibition by tempuyung leaves is unknown.

\section{METHODS}

\section{A. Materials}

The materials used are simplicia of tempuyung leaves from Solo, distilled water, aquabides, ethanol (EtOH) (Merck®), methanol (MeOH) (Merck®), hexane (Merck®), dichloromethane $(\mathrm{CH} 2 \mathrm{Cl} 2) \quad(\mathrm{Merck} \circledast)$, buthanol $(\mathrm{BuOH})$ (Merck®), dimethyl sulfoxide (DMSO) (Merck®), sodium chloride $(\mathrm{NaCl})$ (Merck $®)$, potassium dihydrogen phosphate (KH2PO4) (Merck®), potassium hydrogen phosphate (K2HPO4) (Merck®), ethyl acetate (EtOAc) (Brataco), angiotensin converting enzyme (ACE) (Sigma Aldrich $®)$ and hipuryl histidyl leucine (HHL) (Sigma Aldrich®), and captopril (PT Indofarma).

\section{B. Extraction}

The extraction of simplicia was used the percolation method. A total of $2 \mathrm{~kg}$ of simplicia of tempuyung leaves was percolated using distilled water with a temperature of $80{ }^{\circ} \mathrm{C}$ as much as $300 \mathrm{~L}$. The results of the percolation were evaporated to $20 \mathrm{~L}$ remaining and dried using a spray dryer. The results of the spray dryer are in form of powder with the yield of $228 \mathrm{~g}$.

\section{Water Content}

The porcelain cup is dried in an oven at $105{ }^{\circ} \mathrm{C}$ for 30 minutes, cooled then put in a desiccator for 30 minutes and weighed its empty weight. The sample was weighed about 3 grams and put into a porcelain cup. The sample and the plates were dried at $105{ }^{\circ} \mathrm{C}$ for 5 hours in the oven. After being cooled and put in a desiccator for 30 minutes, the plates and their contents were weighed. The procedure is carried out repeatedly until a fixed weight is obtained by a difference of less than $1 \mathrm{mg}$. Determination of water content was carried out 3 times (triplo). The water content of the sample is calculated by the equation (1):

$$
\text { Water Content }(\%)=\frac{\text { Initial Weight }- \text { Final Weight }}{\text { Initial Weight }} \times 100 \%
$$

\section{Partition}

Crude extract weighed as much as $50 \mathrm{~g}$ and partitioned using a solvent polar, semipolar and nonpolar. The first step, the crude extract was partitioned with $n$-hexane and $90 \%$ $\mathrm{MeOH}-\mathrm{H}_{2} \mathrm{O}$ with a volume ratio of $1: 1$. The $n$-hexane layer was separated from the $90 \% \mathrm{MeOH}-\mathrm{H}_{2} \mathrm{O}$ layer and evaporated using a rotary evaporator and weighed. Furthermore, the $90 \%$ $\mathrm{MeOH}-\mathrm{H}_{2} \mathrm{O}$ layer was diluted using distilled water to $50 \%$ $\mathrm{MeOH}-\mathrm{H}_{2} \mathrm{O}$, then partitioned with $\mathrm{CH}_{2} \mathrm{Cl}_{2}$ with a volume ratio of 1: 1. The $\mathrm{CH}_{2} \mathrm{Cl}_{2}$ layer was separated and evaporated and weighed. Then the remaining of $50 \% \mathrm{MeOH}-\mathrm{H}_{2} \mathrm{O}$ layer was evaporated $\mathrm{MeOH}$ content and repartitioned with $\mathrm{BuOH}$. The $\mathrm{BuOH}$ layer is evaporated and weighed.

\section{E. Inhibition of Angiotensin Converting Enzyme}

Determination of inhibition using the spectrophotometric method according to Cusman and Cheung [19] with modifications. The system consisted of $100 \mu \mathrm{L} 0.1 \mathrm{M}$ phosphate buffer $\mathrm{pH} 8.3$, then added $50 \mu \mathrm{L}$ sample, $50 \mu \mathrm{L}$ 
HHL $5 \mathrm{mM}$, and $50 \mu \mathrm{L}$ ACE $10 \mathrm{mU} / \mathrm{mL}$. The mixture was incubated for 30 minutes at $37^{\circ} \mathrm{C}$, the reaction was stopped by adding $250 \mu \mathrm{L}$ of $1 \mathrm{~N} \mathrm{HCl}$. The product blanked was extracted by adding $1500 \mu \mathrm{L}$ EtOAc then homogenized with the vortex for 1 minute and centrifuged at $4000 \mathrm{xg}$ for 15 minutes. Then the EtOAc layer was separated into a vial and evaporated at 70 ${ }^{\circ} \mathrm{C}$, then added $4 \mathrm{~mL}$ of aquabides and measured using a UVVis spectrophotometer at the maximum wavelength. The measurement results obtained are the absorbance of hippuric acid which is then converted into a concentration and the inhibition is calculated based on the standard curve of hippuric acid obtained.

\section{RESUlTS AND DISCUSSION}

\section{A. Water Content}

Water content is the percentage of water content in a material. Water content affects the resistance of the sample to microbial attack, so that the best handling and storage method can be estimated [20]. This study used a sample of tempuyung from Solo and obtained water content of $4.84 \%$. According to BPOM RI, the moisture content requirement for traditional medicines is $\leq 10 \%$ [21]. According to Winarno [22], if the water content contained in a material is less than $10 \%$, the optimum stability of the material will be achieved, and microbial growth can be reduced. Yulinda [17] examined the water content of tempuyung from three regions, tempuyung from the Bogor area had a water content of $8.07 \%$, tempuyung from Sukabumi had a moisture content of $11.10 \%$, and tempuyung from Bandung had a moisture content of $8.33 \%$. Amalia [18] examined the water content of tempuyung from the Bogor area and the results were $8.07 \%$. The water content obtained from each plant depends on the origin of the plant obtained, each region has different weather and humidity at different times.

\section{B. Yield of Extracts}

Extraction is taking of a single or multiple compounds based on its distribution in 2 phases with certain solvents [23]. The extraction process is influenced by several factors, including the type of solvent used and the contact surface area between solvent and sample. The extraction method used in this study is percolation. Percolation is a type of liquid solid extraction which is carried out by slowly flowing the solvent into the sample in a percolator [24]. This study used $2 \mathrm{~kg}$ of simplicia of tempuyung and obtained $228 \mathrm{~g}$ of percolated extract with a yield of $11.98 \%$. The extract obtained was then extracted again by the liquid-liquid partition method using three types of solvents with different polarity, namely $n$ hexane, $\mathrm{CH}_{2} \mathrm{Cl}_{2}$, and $\mathrm{BuOH}$. Partitioning is an absorption process that is analogous to solvent extraction [25].
TABLE I.

YIELDS OF TEMPUYUNG LEAF EXTRACT
\begin{tabular}{|l|l|}
\hline \multicolumn{1}{|c|}{ Fraction } & Yield $(\%)$ \\
\hline $\mathrm{BuOH}$ & 2.43 \\
\hline $\mathrm{CH}_{2} \mathrm{Cl}$ & \\
\hline$n$-Hexane & 0.77 \\
\hline
\end{tabular}

Based on Table I, $50 \mathrm{~g}$ of tempuyung extract used, the layer $n$-hexane produced the least yield, followed by the $\mathrm{CH}_{2} \mathrm{Cl}_{2}$, and $\mathrm{BuOH}$ layer produced the highest yield. The degree of polarity of a solvent affects the amount of bioactive compounds in tempuyung leaves that can be drawn into the layer, it is possible that the bioactive compounds that are polar in tempuyung leaves are more than compounds that are semipolar or nonpolar. The high yield in the $\mathrm{BuOH}$ layer indicates that the solvent is able to extract more bioactive components which have higher polarity properties [26]. The yield in the $\mathrm{CH}_{2} \mathrm{Cl}_{2}$ layer was smaller than that of the $\mathrm{BuOH}$ layer but greater than that of the $n$-hexane layer. The smallest yield value obtained in the $n$-hexane layer indicated that the nonpolar bioactive compounds in the tempuyung leaves extract were few.

Khan [27] reported that in the ethanol extract of tempuyung leaves, there are several polar compounds, namely orientin, hyperosid, quercetin, catechins, routine, myristine, and kaempferol. The chemical compounds of the flavonoid group contained in tempuyung leaves are known to be luteolin-7-Oglucoside and apigenin-7- $O$-glucoside [12], 7,4-dihydroxy flavones [11], and derivatives quinic acid is 1,3,4,5-tetra- $(P-$ hydroxyphenylacetyl) [28]. The semipolar compounds that were successfully synthesized from the ethyl acetate layer of the ethanol extract of tempuyung leaves were isoquinolines from the alkaloid group [29], and Rumondang [13] succeeded in synthesizing triterpenoids froms $n$-hexane solvent of ethanol extract of tempuyung leaves.

\section{Inhibition of tempuyung extract and fraction to ACE activity}

ACE is a glycoprotein peptidyl dipeptide hydrolase which basically catalyzes the reaction of angiotensin I to angiotensin II, by breaking the histidyl-leucine dipeptide from the C-end angiotensin I or hippuryl-histidyl leucine (HHL) which is a substrate and produces angiotensin II or hippuric acid (main product) (Scheme 1). ACE inhibitors work by inhibiting performance of ACE in the formation of hippuric acid [30]. So that the measurement of inhibition of ACE activity is measured from the concentration of hippuric acid obtained. The greater the inhibition of the sample toward ACE activity, so the lower the measured hippuric acid concentration. This study measured the inhibition of crude extract and various solvents with different polarity, namely $n$-hexane, $\mathrm{CH}_{2} \mathrm{Cl}_{2}$, and $\mathrm{BuOH}$ in tempuyung leaves extract toward ACE activity in vitro and compared with a synthetic drug, namely captopril. The inhibition test was intended to determine the ability of layers of $n$-hexane, $\mathrm{CH}_{2} \mathrm{Cl}_{2}$, and $\mathrm{BuOH}$ of tempuyung leaves extract to inhibit ACE activity which was expressed in percent units. The mechanism of ACE inhibition by ACE inhibitors is known as competitive inhibition [31]. ACE inhibitor will compete with 
HHL to bind to the active site of ACE, thus formation of hippuric acid can be prevented.

The crude extract of tempuyung leaves was dissolved using phosphate buffer $\mathrm{pH} 8.3$ at concentrations of 5, 10, 25, 50, 100, 500, 750, and $1000 \mu \mathrm{g} / \mathrm{mL}$. Fig. 1 shows that overall, the inhibition of tempuyung leaves crude extract toward ACE was not significantly different in the concentration range. The percentage of inhibition obtained was not linear with increasing concentration. There was a significant decrease in inhibitory power at a concentration of $100 \mu \mathrm{g} / \mathrm{mL}$, but the inhibition again increased at a concentration of $500 \mu \mathrm{g} / \mathrm{mL}$ and decreased again to a concentration of $1000 \mu \mathrm{g} / \mathrm{mL}$. This nonlinearity occurs because the crude extract still contains several groups of compounds, so it is suspected that an antagonistic response occurs and affects each other.

The crude extract was partitioned using three different types of solvents, namely $\mathrm{BuOH}, \mathrm{CH}_{2} \mathrm{Cl}_{2}$, and $n$-hexane. Then each layer was measured the inhibition toward ACE at concentrations of $5,10,25,50,100,500$, and $1000 \mu \mathrm{g} / \mathrm{mL}$. However, the $\mathrm{CH}_{2} \mathrm{Cl}_{2}$ and $n$-hexane layers were not able to dissolve in phosphate buffer $\mathrm{pH} 8.3$ at concentrations of 100 , 500 , and $1000 \mu \mathrm{g} / \mathrm{mL}$, so it was not tested in this study. However, the $\mathrm{CH}_{2} \mathrm{Cl}_{2}$ and $n$-hexane layers were still soluble at concentrations of 200 and $250 \mu \mathrm{g} / \mathrm{mL}$, so they were tested at these two concentrations. The inability of the phosphate buffer $\mathrm{pH} 8.3$ to dissolve the $\mathrm{CH}_{2} \mathrm{Cl}_{2}$ and $n$-hexane layer of tempuyung leaves extract at high concentration. This is possible because there are at least compounds with the same polarity properties, so that they don't meet one of the solubility requirements, namely like dissolve like [23].

The highest inhibition in the $\mathrm{BuOH}$ layer is at a concentration of $25 \mu \mathrm{g} / \mathrm{mL}$, which is $44.98 \%$, while the $\mathrm{CH}_{2} \mathrm{Cl}_{2}$ layer is at concentration of $50 \mu \mathrm{g} / \mathrm{mL}$, which is $42.37 \%$. and in the $n$-hexane layer is found at concentration of $50 \mu \mathrm{g} / \mathrm{mL}$ which is $39.36 \%$. These data indicate that at lower concentrations, the $\mathrm{BuOH}$ layer was able to provide higher inhibitory power than the $\mathrm{CH}_{2} \mathrm{Cl}_{2}$ and $n$-hexane layers. This suggests the possibility of compounds eight bioactive on leaf extract tempuyung polar. At a concentration of $100 \mu \mathrm{g} / \mathrm{mL}$ to $1000 \mu \mathrm{g} / \mathrm{mL}$ the inhibition of the sample toward ACE tended to decrease (Fig. 2). The sample used still contained various kinds of compounds (multicomponent). It is also suspected that there are components that work as activators. At high concentrations, this component plays a greater role in enzymatic reactions thereby increasing enzyme activity or in other words reducing enzyme inhibition. This causes the inhibition of the extract at high concentrations to decrease. The percentage of inhibition of the three layers has fluctuated, several things that may be the cause of the fluctuating inhibition value are tests that are not carried out at temperature, $\mathrm{pH}$, substrate and enzyme concentrations that are not yet optimum [32]. ACE is reported to be stable for less than 6 months at $5{ }^{\circ} \mathrm{C}$ storage at $\mathrm{pH} 5-9$, ACE is easily denatured at high temperatures resulting in $60 \%$ of its activity being lost after 15 minutes of preincubation at 60 ${ }^{\circ} \mathrm{C}[19]$.

Captopril (N- [(S) -3-Mercapto-2-methylpropionyl]-Lproline) was used as a positive control to inhibition of ACE activity. Captopril was the first ACE inhibitor followed by enalapril, lisinopril, perindopril, ramipril, cilasapril, fosinopril, quinapril, and so on. All types of drugs that work as ACE inhibitors have an equal antihypertensive effect, the difference lies in the length of action and the ability to control blood pressure for 24 hours [33]. Captopril has side effects of cough and angioneurotic edema [34]. Captopril had the highest inhibition percentage at $25 \mu \mathrm{g} / \mathrm{mL}$ at $47.99 \%$. Based on the results of this study, tempuyung leaves have the ability to inhibit ACE activity. The $\mathrm{BuOH}$ layer had an inhibition of $44.97 \%$, which was the highest of the $\mathrm{CH}_{2} \mathrm{Cl}_{2}$ and $n$-hexane layers (Fig. 3). Based on the results obtained, it appears that the inhibition of the $\mathrm{BuOH}$ layer is close to that of captopril. If this layer is further purified so that a higher concentration is obtained, it can be assumed that the $\mathrm{BuOH}$ layer of the tempuyung leaves aqueous extract will exceed the inhibition of captopril.

As well as being a potential ACE inhibitor, [35] reported that tempuyung has cardioprotective properties that protect the heart considering hypertension is a cardiovascular disease. Tempuyung leaves are also known to have effectiveness as a diuretic, anti-inflammatory and antipyretic, and contain flavonoids in the form of luteolin [36], and contains kaempferol, orientin, and quercetin [27]. A study shows that quercetin in plants has activity in cardiovascular disease, such as lowering blood pressure [37].

Harjana [38] and Aproyanti [39] state that compounds that can reduce high blood pressure are flavonoids. Flavonoids are polyphenolic chemical compounds that can be characterized through pharmacological activities such as antioxidants, antiinflammatory, antiviral and anti-tumor properties. This activity can occur due to the ability of flavonoids to inhibit enzymes such as trypsin, protein kinase, and topoisomerase [40]. Other research studies have generally shown that the active compounds for antihypertensives come from the flavonoid class compounds, including flavan-3-ol and procyanidin [41]. The active compound quercetin is one of the flavonoid compounds that have been tested for antihypertension in vitro $[42,43]$. 


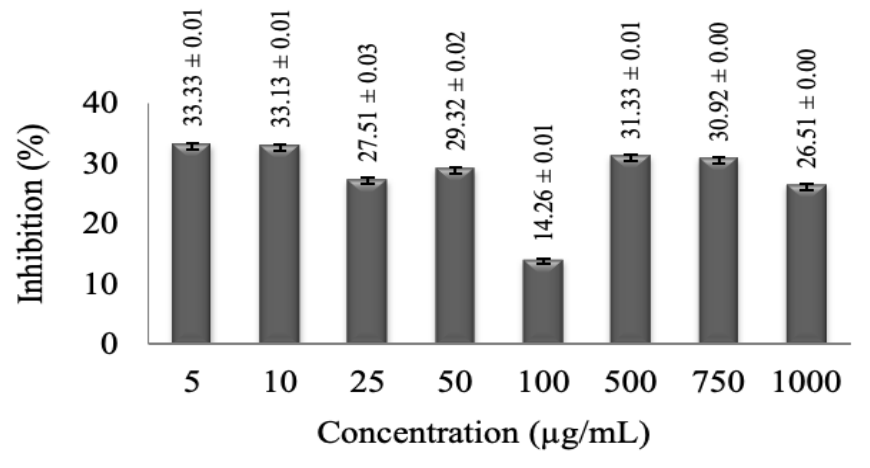

Fig. 1. Inhibition of crude extract of tempuyung leaves toward ACE.

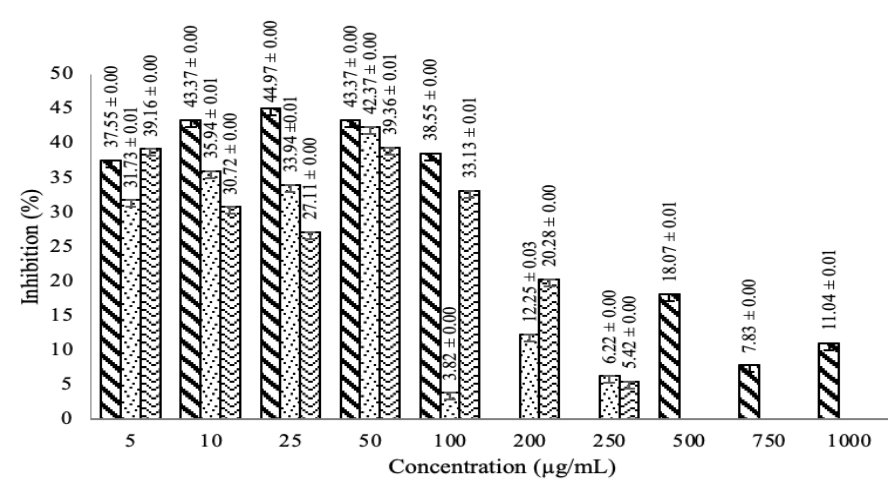

Fig. 2. Inhibition of tempuyung leaves extract in $\mathrm{BuOH}$ (\$), $\mathrm{CH} 2 \mathrm{Cl} 2$ (ख), and n-hexane (㡠) solvents toward ACE.

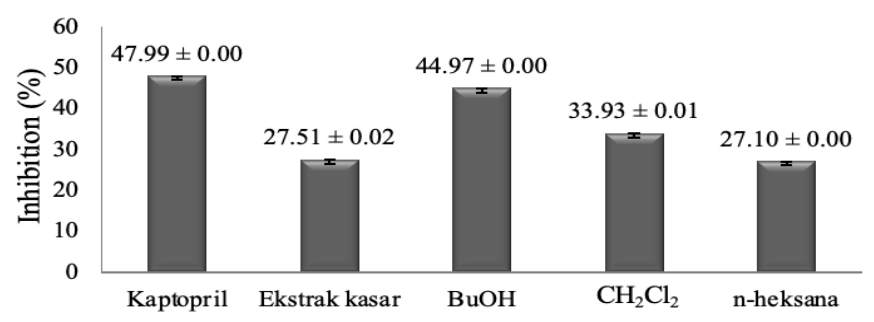

Fig. 3. Inhibition of samples toward ACE at a concentration of $25 \mu \mathrm{g} / \mathrm{mL}$.

\section{CONCLUSION}

Inhibition of single extract of tempuyung leaves (Sonchus arvensis) toward angiotensin converting enzyme (ACE) activity in vitro based on solvent polarity provides better inhibition than crude extract assay. The $\mathrm{BuOH}$ layer gave the highest percentage of inhibition compared to $n$-hexane and $\mathrm{CH}_{2} \mathrm{Cl}_{2}$ layers, and almost resemble percentage of inhibition of the synthetic drug (captopril). The polar layer in tempuyung leaves extract has the potential to be developed as an antihypertensive drug.

\section{REFERENCES}

[1] S. Suyono, W. Sarwono, L. Laurentius, A. Idrus, S. Siti, D. Dharmika, Suhardjono, W.S. Aru, B. Asrul, and Mudjadid, Buku Ajar Ilmu Penyakit Dalam Jilid II, Jakarta (ID): Fakultas Kedokteran Universitas Indonesia, 2001.

[2] Y. Iskandar, Tanaman Obat yang Berkhasiat Sebagai Antihipertensi, Bandung (ID): Universitas Padjajaran, 2007.

[3] Y. Prasetyaningrum. Hipertensi Bukan untuk Ditakuti, Jakarta (ID): Fmedia, 2014.

[4] [Kemenkes], "Hasil utama riset kesehatan dasar (riskesdas) 2018, Jakarta (ID): Badan Penelitian dan Pengembangan Kesehatan, 2018

[5] T. Tjay, K. Rahardja, Obat-Obat Penting: Kasiat, Penggunaan, dan Efek Efek Sampingnya, Jakarta (ID): Gramedia Pustaka Utama, 1964.

[6] D.P. Bicket, "Using ACE inhibitors approprietly," Am. Fam. Physician, vol. 66, pp. 461-468.

[7] K. Hansen, et al., "In vitro screening of traditional medicines for antihypertensive effect based on inhibiton of the angiotensin converting enzyme (ACE)," J. Ethnopharmacol, vol. 48, pp. 43-51, 1995.

[8] Nafrialdi, Farmakologi dan Terapi: Antihipertensi. Jakarta (ID): Gaya Baru, 2007.

[9] W.P. Winarto, Tempuyung: Tanaman Penghancur Batu Ginjal, Jakarta (ID): Agromedia Pustaka, 2004.

[10] Lawrence, Taxonomi of Vascular Plants, New York (US): The Macmillan Company, 1958.

[11] Sriningsih, H.W. Adji, W. Sumaryono, A.E. Wibowo, Cardir, Firdayani, S. Kusumaningrum, and P. Kartakusuma, "Analisa senyawa golongan flavonoid herba tempuyung (Sonchus arvensis L.) [laporan penelitian], Jakarta (ID): Pusat P2 Teknologi Farmasi dan Medika Deputi Bidang TAB BPPT, 2002.

[12] .J. Sulaksana, S. Budi, and I. Dadang, Tempuyung Budi Daya dan Pemanfaatan Untuk Obat, Jakarta (ID): Penebar Swadaya, 2004.

[13] M. Rumondang, "Isolasi, identifikasi dan uji antibakteri senyawa triterpenoid dari ekstrak n-heksana daun tempuyung (Sonchus arvensis L.)," Chem. Info, vol. 1, pp. $156-164,2012$.

[14] W. Yuliarti, D. Kusrini, and E. Fachriyah, "Isolasi, identifikasi dan uji antioksidan asam fenolat dalam daun tempuyung (Sonchus arvensis L.) dengan metode 1,1-difenil-2-pikrilhidrasil (DPPH)," Chem. Info, vol. 1, pp. 294-304, 2012.

[15] [Deptan], "Rumusan Forum Koordinasi Kelembagaan Produksi Aneka Tanaman," in Prosiding Forum Koordinasi Kelembagaan Produksi Aneka Tanaman. Jakarta (ID), 2002.

[16] L. Budiman, Inhibisi ekstrak pegagan (Centella asiatica) and tempuyung (Sonchus arvensis) terhadap aktivitas ACE (angiotensin converting enzyme), Bogor (ID) : Institut Pertanian Bogor.

[17] L. Yulinda, "Inhibisi ekstrak etanol kumis kucing, pegagan, sambiloto, dan tempuyung terhadap aktivitas enzim pengubah angiotensin I secara in vitro [skripsi], Bogor (ID): Institut Pertanian Bogor, 2011.

[18] L.T. Amalia, "Uji khasiat blankula antihipertensi secara preklinik dan mekanisme kerjanya secara in vitro," Institut Pertanian Bogor, 2017.

[19] D.W. Cushman, and H.W. Cheung, "Spectrophotometric assay and properties of the angiotensin converting enzyme of the rabbit lung," Biochem. Pharmacol, vol. 20, pp. 1637-1648, 1971.

[20] S. Fardiaz, Analisis Mikrobiologi Pangan, Jakarta (ID): Raja Grapindo Persada, 1989.

[21] BPOM, Persyaratan Mutu Obat Tradisional, Jakarta (ID): Badan Pengawas Obat dan Makanan, 2014.

[22] [F.G. Winarno, Kimia Pangan dan Gizi, Jakarta (ID): Gramedia Pustaka Utama, 1997.

[23] R.A. Day, and A.L. Underwood, "Analisis Kimia Kuantitatif. Six edition, Sopyan I, translator, Jakarta (ID): Erlangga, 2002.

[24] M. Leba, Ekstraksi dan Real Kromatografi, Yogyakarta (ID): Deepublish, 2017. 
[25] A. Rohman, Kimia Farmasi Analisis, Jakarta (ID): Pustaka Pelajar, 2007.

[26] N. Ukhty, Kandungan senyawa fitokimia, total fenol dan aktivitas antioksidan Lamun (Syringodium isoetifolium) [skripsi], Bogor (ID): Institut Pertanian Bogor, 2011.

[27] R. Khan, "Evaluation of flavonoids and diverse antioxidant activities of Sonchus arvensis," Chemistry. Central. J, vol. 6, 2012.

[28] Y. Xu, S. Sun, L. Sun, D. Qiu, X. Liu, Z. Jiang, and C. Yuan, "Quinic acid esters and sesquiterpenes from Sonchus arvensis," Food. Chemistry, vol. 111, pp. 92-97, 2008.

[29] Y. Murtadlo, "Isolasi, identifikasi senyawa alkaloid total daun tempuyung (Sonchus arvensis L.) dan uji sitotoksik dengan metode BSLT (brine shrimp lethality test)," Chem. Info, vol. 1, pp. 379-385, 2013.

[30] L.T. Skeegs, K.E. Lentz, J.R. Kahn, and N.P. Shumway, "The synthesis of a tetradecapeptide renin substrate," Experimental Medicine, vol. 108, pp. 283-297, 1958.

[31] N.J. Brown, and D.E. Vaughan, "Angiotensin-converting enzyme inhibitors," Circulation.

[32] A. Supriyatno, "Manfaat jamur pelapuk putih Phanerochaete chrysosporium L1 dan Pleurotus Eb9 untuk biobleaching pulp kardus bekas [skripsi], Bogor (ID): Institut Pertanian Bogor, 2009.

[33] W. Prodjosudjadi, "Hipertensi : mekanisme dan penatalaksanaan,”Berkala Neurosains, vol. 1, pp. 133-139, 2000.

[34] Z.H. Israili, and W.D. Hall, "Cough and angioneurotic edema associated with angiotensin converting enzyme inhibitor therapy: a review of the literature and phatophysiology," Ann. Intern. Med, vol. 117, pp. 234242, 1992.
[35] N. Kurniati, E. Sukandar, R. Pardilah, N. Suliska, and D. Ayuningtyas, "Cardioprotective potential of ethanol extract of Sonchus arvensis L. leaves on isoproterenol-induced myocardial infarction in rat," Ilmu. Kefarmasian. Indonesia, vol. 16, pp. 20-24, 2018.

[36] D. Bramwell, and K. Dakshini, "Luteolin 7-O-glucoside and hydroxycoumarins in canary island Sonchus species," Phytochemistry, vol. 10, pp. 2245-2246, 1971.

[37] A.J. Larson, J.D. Symons, and T. Jalili, “ Therapeutic potential of quercetin to decrease blood pressure: review of efficacy and mechanisms," Adv. Nutr, vol. 3, pp. 39-46, 2012.

[38] T. Harjana, "Kajian Tentang Potensi Bahan-Bahan Alami untuk Menurunkan Kadar Kolesterol Darah," in Prosiding Seminar Nasional Penelitian, Pendidikan dan Penerapan, FMIPA Universitas Negeri Yogyakarta: Yogyakarta (ID), 2011.

[39] M. Apriyanti, Sepuluh Tanaman Obat Paling Berkhasiat dan Paling Dicari. Pustaka Baru Pr, Jakarta, 2012.

[40] M. Barolli, A. Werner, L. Slep, and A. Pamillo, "Blankation of complexes of flavonoids and metals, determination of the stochiometry and stability constants," Molecules, vol. 5, pp. 516-517, 2000.

[41] L. Actis-Goretta, J. Ottaviani, C. Keen, and C. Fraga, "Inhibition of angiotensin converting enzyme (ACE) activity by flavan-3-ol and procyanidin," FEBS. Lett, vol. 555, pp. 597-600, 2003.

[42] J. Duarte, R. Perez-Palencia, F. Vargas, M. Ocete, F. Perez-Vizcano, A. Zarzuelo, and J. Tamargo, "Antihypertensive effects of the flavonoid quercetin in spontaneously hypertensive rats," Brit. J. Pharmacol, vol. 133, pp. 177-124, 2001.

[43] F. Perez-Vizcaino, J. Duarte, R. Jimenez, C. Santos-Buelga, and A. Osuna,"Antihypertensive effects of the flavonoid quercetin," Pharmacol, vol. 61, pp. 67-75, 2009. 